\title{
Ilmenite generations in orangeite from Banankoro, Guinea: implications for exploration
}

\author{
Jingyao Xu' ${ }^{1}$, Joan Carles Melgarejo ${ }^{2}$, Montgarri Castillo-Oliver ${ }^{3}$, Laia Arqués ${ }^{4}$, Joan \\ Santamaria ${ }^{5}$ \\ (1) Departament de Mineralogia, Petrologia i Geologia Aplicada, Facultat de Ciències de la Terra, Universitat \\ de Barcelona, C/Martí i Franquès s/n,08028 Barcelona, Spain.jingyao.xu@ub.edu \\ (2) Departament de Mineralogia, Petrologia i Geologia Aplicada, Facultat de Ciències de la Terra, Universitat \\ de Barcelona, C/Martí i Franquès s/n,08028 Barcelona, Spain.joan.carles.melgarejo.draper@ub.edu \\ (3) ARC Centre of Excellence for Core to Crust Fluid Systems and GEMOC, Department of Earth and Planetary \\ Sciences, Macquarie University, NSW 2019, Australia.montgarri.castillo-oliver@mq.edu.au \\ (4) Departament d'Energia Solar, Institut de Recerca en Energia de Catalunya. Jardins de les Dones de Negre \\ 1,2n pis.08930Sant Adrià delBesòs,Spain.larques@irec.cat \\ (5) Consultant Geologist, Sabadell, Spain.joan.guinea.casanovas@gmail.com
}

\section{Introduction}

Ilmenite is one of the classic diamond indicator minerals (DIMs) and for long it has been used as a guide for kimberlite exploration. Mg-rich ilmenite is commonly found either as a xenocryst or as a replacement product of ilmenite xenocrysts. However, ilmenite is not present in all kimberlites worldwide, and $\mathrm{Mg}$-ilmenite is rarely documented as a euhedral crystal component of the kimberlite groundmass (Boctor and Boyd, 1980; Haggerty, 1975). The discovery of euhedral Mg-ilmenite crystals in the groundmass of a pipe in the Banankoro area (Guinea) offers a good opportunity to study the textural relations between the different ilmenite generations and the rest of the minerals.

The kimberlites from Banankoro (Guinea) are found in the Man craton, West Africa. The Banankoro kimberlite age was obtained by ${ }^{40} \mathrm{Ar} /{ }^{39} \mathrm{Ar}$ for phlogopite about $139 \pm 3 \mathrm{Ma}$ (Skinner et al., 2004). Most of the Man craton kimberlites were classified as phlogopite kimberlites, although $\mathrm{K}$ contents are relatively low (Skinner et al., 2004).

\section{Petrography}

The samples studied here are hypabyssal, and they consist of corroded xenocrysts of olivine (30\% modal), phlogopite ( $<1 \%$ modal) and geikielite $(<1 \%$ modal $)$ settled in a groundmass ( $68 \%$ modal). On its turn, the groundmass is made up of olivine microphenocrysts altered to serpentine group minerals $(40 \%)$, phlogopite (38\%), calcite (16\%), spinel-group minerals $(6 \%)$ and lesser amounts of perovskite, apatite and ilmenite.

Phlogopite macrocrysts (about $2 \mathrm{~mm}$, phlogopite 1) show a reaction rim (phlogopite 2), and they are replaced by a second rim (phlogopite 3). Similarly, groundmass phlogopite has a rounded core of Tirich phlogopite (phlogopite 4) replaced by a tetraferriphlogopite rim (phlogopite 5).

Many textural populations of the spinel-group minerals occur in the groundmass. The first one is hemihedral, atoll-shaped and frequently zoned, with a chromite core (spinel 1). It is replaced by another euhedral chromite (spinel 2). Another chromite with different composition (spinel 3) is found together with the spinel 2 included in phlogopite 3 . Both spinels may also be mantled by a zoned titanomagnetite rim (spinel 4 and 5). Titanomagnetite (spinel 6) replaces geikielite xenocrysts. Euhedral unzoned titanomagnetite (spinel 7) occurs in rounded massive cloudy aggregates, along with phlogopite.

Four compositional-textural ilmenite types are discriminated. Type $1 \mathrm{Mg}$-rich ilmenite is anhedral and it is replaced by spinel 6. Type 2 ilmenite is Mg-rich, it occurs as euhedral tabular crystals (about 200 $\mu \mathrm{m}$ ), which grew in small cavities along with earlier calcite. This ilmenite may replace spinel and it is replaced by a late generation of Mn-rich ilmenite (type 3 ) along the borders and fractures. Type 4 ilmenite is Mn-rich ilmenite and it replaces the perovskite margins. 
Perovskite in groundmass is euhedral to hemihedral and it is slightly zoned. It is replaced by type $4 \mathrm{Mn}-$ rich ilmenite.

\section{Mineral chemistry}

Spinel 1 do not follow the typical spinel trends, and it has lower $\mathrm{Al}(0,13-0,15 \mathrm{apfu}), \mathrm{Mg}(0,40-0,43$ apfu), and $\mathrm{Ti}(0,05-0,07)$ but higher $\mathrm{Fe}^{2+}(0,59-0,64 \mathrm{apfu})$ and $\mathrm{Fe}^{3+}(0,46-0,54 \mathrm{apfu})$ contents than spinel 2 (0,16-0,32 apfu Al, 0,57-0,61 apfu Mg and 0,12-0,19 apfu Ti; 0,49-0,58 apfu Fe ${ }^{2+}$ and 0,22-0,42 apfu $\left.\mathrm{Fe}^{3+}\right)$. Spinel 2 is magnesiochromite with $0,79-0,89 \mathrm{Cr}$. There is an increase in $\mathrm{Ti} /(\mathrm{Ti}+\mathrm{Al}+\mathrm{Cr})$, $\mathrm{Fe}^{2+} /\left(\mathrm{Fe}^{2+}+\mathrm{Mg}\right)$ and $\mathrm{Fe}^{3+} /\left(\mathrm{Fe}^{3+}+\mathrm{Al}+\mathrm{Cr}\right)$ from spinel 2 to spinel 5. This compositional trend crosses the T1 and T2 fields established by Mitchell (1986), as well as the kimberlite trend and Fe-Ti trend defined by Barnes and Roeder (2001). Titanomagnetite (spinel 6) replaces Mg-rich ilmenite and hence it is enriched in Mg. The euhedral titanomagnetite (spinel 7) has a composition between spinel 3 and spinel 4.

Type $1 \mathrm{Mg}$-rich ilmenite is classified as geikielite $(0,52-0,58$ apfu $\mathrm{Mg})$, it has higher $\mathrm{Cr}$ than the other ilmenite types (up to 2,7 wt.\% $\mathrm{Cr}_{2} \mathrm{O}_{3}$ ), and very low $\mathrm{Mn}$ and $\mathrm{Nb}$ contents $(0,5-0,8 \mathrm{wt} . \% \mathrm{MnO}$ and $\sim 0,1$ wt.\% $\mathrm{Nb}_{2} \mathrm{O}_{5}$ ). Type 2 euhedral tabular ilmenite is Mg-rich (0.30-0.48 Mg apfu), with low $\mathrm{Mn}$ and $\mathrm{Nb}$ contents $\left(1,5-2,4\right.$ wt. \% $\mathrm{MnO}$ and $0,4-1,4$ wt.\% $\left.\mathrm{Nb}_{2} \mathrm{O}_{5}\right)$. Type 3 ilmenite is slightly enriched in $\mathrm{Mn}$ (2,57-4,5 wt. \% $\mathrm{MnO})$ but it has low $\mathrm{Mg}$ and $\mathrm{Cr}$ contents $\left(0,5-2,7 \mathrm{wt} . \% \mathrm{MgO}\right.$ and $0-0,4$ wt. $\left.\% \mathrm{Cr}_{2} \mathrm{O}_{3}\right)$. It has enrichment in $\mathrm{Nb}\left(0,7-2.5\right.$ wt. $\left.\% \mathrm{Nb}_{2} \mathrm{O}_{5}\right)$, with high $\mathrm{Fe}^{2+}\left(0,8-0,9\right.$ apfu) and low $\mathrm{Fe}^{3+}(<0,1 \mathrm{apfu})$. Type 4 ilmenite is poor in $\mathrm{Mg}$ and $\mathrm{Cr}$ but it is slightly enriched in $\mathrm{Mn}(3,2-4,9 \mathrm{wt} . \% \mathrm{MnO})$ and $\mathrm{Nb}$. Type 1 ilmenite compositions plot in the kimberlitic domain (Wyatt et al., 2004), while types 2, 3 and 4 plot outside. However, it shows a Mn enrichment from type 2 to type 4 ilmenite. Type 1 has the highest $\mathrm{Fe}^{3+}$ and $\mathrm{Mg}$ contents.

The phlogopite macrocrysts (type 1) are Al-rich (1,95-1,98 apfu) and Ti-poor (0,02-0,03 apfu). Phlogopite 2 is Al-rich (about 2,42 apfu) and Ti-rich (0,40-0,41 apfu). Phlogopite 3 (outer rim) has the same composition as the core of groundmass phlogopite (phlogopite 4), which is Ti-rich $(0,14-0,20$ apfu) and Al-rich (1,58-1,80 apfu). These evolve to Al-free (0-0,07 apfu) and Ti-poor (0,02-0,04 apfu) tetraferriphlogopite, thus following the orangeite trend defined by Mitchell (1995). They have 1,491,70 apfu $\mathrm{Fe}^{3+}$ in the tetrahedral position.

Perovskite in groundmass is slightly zoned, the cores having higher LREE content $(5,0-5,7 \mathrm{wt} . \% \Sigma$ $\mathrm{LREE}_{2} \mathrm{O}_{3}$ ) than the borders (up to 1,2-3,9 wt.\% $\sum \mathrm{LREE}_{2} \mathrm{O}_{3}$ ). Nb contents are quite constant and low $\left(0,8-1,8\right.$ wt. $\left.\% \mathrm{Nb}_{2} \mathrm{O}_{5}\right)$.

\section{Discussion and conclusions}

The high modal phlogopite and the tetraferriphlogopite trend (Tappe et al., 2005) are indicative of an orangeite affinity for this pipe. However, the occurrence of an early generation of phlogopite with an "alnoite or minette" trend would indicate the existence of an early different magma.

The diversity of spinel and ilmenite generations also records a very complex evolution of this magma. The origin of the type 1 spinel remains obscure, but since it is replaced by the younger chromite generations it could be produced by an early magma of unclear composition. However, the coexistence of type 2 and type 3 spinels (as demonstrated by their occurrence in same growth band of phlogopite) suggests the coexistence of two separate magmas (a possible magma mingling) in this intrusion. At the least, the chemical evolution of the zoned spinels (types 2,4,5) can fit the evolution of an orangeite magma, but the higher $\mathrm{Mg}$ compositions of the type 3 could also suggest the existence of a more kimberlitic magma. However, one must take into account that the composition of spinel 6 can be interpreted as produced by the same magma as type 4 spinel, but enriched in $\mathrm{Mg}$ because it replaces geikielite. Moreover, the occurrence of dense spinel aggregates with a distinct composition (type 7 spinel) can be indicative of another Fe-rich magma of nelsonitic affinity. 
Mg-rich ilmenite is commonly found as macro- and megacryst in kimberlite, and it is interpreted as produced by primary magmatic crystallization (Moore,1987) or as xenocrysts (Armstrong et al., 2004). However, it is found in most of the cases as a replacement product of oxidized ilmenite xenocrysts (Robles-Cruz et al., 2009). Hence, type 1 ilmenite (geikielitic) from Banankoro could be produced by a similar mechanism, because its composition is typically within the kimberlitic domain of Wyatt et al. (2004). This process took place clearly before the crystallization of the groundmass spinel. However, euhedral Mg-rich ilmenite is very different to the other ilmenite generation, also in compositions. Firstly, type 2 euhedral tabular ilmenite from Banankoro plots out of the kimberlite domain in the compositional diagram of Wyatt et al. (2004), and it has a higher Mn contents. Moreover, type 2 ilmenite crystallised as a late product in association with calcite and serpentines, mantling spinels and other groundmass minerals. Therefore, it cannot have any relation with the metasomatic processes in the mantle producing the diamond growth.

Finally, although type $3 \mathrm{Mn}$-ilmenite has been suggested as a guide for diamond exploration, in Banankoro is clearly a late product replacing Mg-rich euhedral ilmenite and all the spinel minerals. Therefore, its formation is most likely linked to hydrothermal fluids given its systematic association with serpentines.

\section{Acknowledgments}

This research was supported the AGAUR 2014SGR01661 of the Generalitat de Catalunya and a FI grant to J. Xu (coded FI B 00904) sponsored by the Departament d'Educació i Universitats de la Generalitat de Catalunya. The authors also acknowledge the Servei de Làmina Prima and the Centres Científics i Tecnològics de la Universitat de Barcelona (CCiT-UB) for the assistance with SEM-BSEEDS study (Dr. F. J. García-Veigas, D. Artiaga) and EMP analyses (Dr. Xavier Llovet).

\section{References}

Armstrong KA, Nowicki TE, Read GH (2004) Kimberlite AT-56: a mantle sample from the north central Superior craton, Canada. Lithos 77: 695-704

Barnes SJ, Roeder PL, (2001) The range of spinel compositions in terrestrial mafic and ultramafic rocks. J. Petrol. 42: 2279-2302

Boctor N, Boyd F (1980) Oxide minerals in the Liqhobong kimberlite, Lesotho. Am. Min. 65: 631-638

Haggerty SE, (1975) The chemistry and genesis of opaque minerals in kimberlites: Physics and Chemistry of the Earth 9: 295- 307

Mitchell RH (1995) Kimberlites, Orangeites, and Related Rocks. Plenum Press. New York, 410 pp

Moore AE (1987) A model for the origin of ilmenite in kimberlite and diamond: implications for the genesis of the discrete nodule (megacryst) suite. Contrib Mineral. Petrol. 95: 245-253

Robles-Cruz SE, Watangua M, Isidoro L, Melgarejo JC, Galí A, Olimpio A (2009) Contrasting compositions and textures of ilmenite in the Catoca kimberlite, Angola, and implications in exploration for diamond. Lithos 112: 966-975

Skinner EMW, Apter DB, Morelli C, Smithson NK. (2004) Kimberlites of the Man Craton, West Africa. Lithos 76: 233-259

Tappe S, Foley SF, Jenner GA, Kjarsgaard BA (2005) Integrating ultramafic lamprophyres into the IUGS classification of igneous rocks: rationale and implications. J. Petrol. 46: 1893-1900

Wyatt BA, Mike B, Anckar E, Grütter H (2004) Compositional classification of "kimberlitic" and "nonkimberlitic" ilmenite. Lithos 77: 819-840 